\title{
Concept for Ecotourism Industry: Over View from out to in (Ethiopia). A Review Articles
}

\author{
Bayisa Bussa Gonfa \\ Department of Natural Resources Management, College of Agriculture Science, \\ Bule Hora University, P.O.Box: 144, Bule Hora, Ethiopi
}

\begin{abstract}
Ecotourism is an important and rapidly growing "niche market" within the global tourism industry, which can contribute to environmental conservation, socio-economic and gives value to the maintenance of local traditions and culture. The evolution of the concept of ecotourism could be traced from the 1980s, which coincides with the grounding of the concept of sustainable development. Although it has been difficult to calculate the size and growth rate of ecotourism, a range of estimates indicate that it has become the fastest growing sub-sector of the tourism industry. The contribution of ecotourism to rural livelihoods and livelihood diversification has received significant research attention and taken as determinants of livelihood outcomes. Ethiopia is a country of land of multiple tourist attractions and a visitor friendly people who are conscious of its historical, cultural and natural heritages in its regions. Even though it possesses a plethora of tourist attractions, yet tourism infrastructure, tourist products and marketing are at its infancy. The sector has direct, indirect and induced impact on the country's economy, environment and cultural resources. To sustain sustainable development for the long run from the sector, balancing those impacts and giving attention towards peace and security as well as infrastructure development is crucial as the ecotourism industry mainly depend on them.
\end{abstract}

Keywords: Ecotourism, Community, Tourism, Impact

DOI: $10.7176 / \mathrm{JTHS} / 51-02$

Publication date:October $31^{\text {st }} 2020$

\section{Introduction}

\subsection{Over view of Ecotourism Industry (from out to Ethiopia)}

Ecotourism, which is a unique subset of the tourism industry, focuses on the maintenance of natural systems through tourism activities and initially used to describe nature based travel to relatively undisturbed areas with an emphasis on education, conserves the environment and improves the well-being of local people (Fasika, 2017). It is "environmentally responsible travel and visitation to relatively undisturbed natural areas to enjoy and appreciate nature (including any accompanying cultural features both past and present), that promotes conservation, has low visitor impact and provides for beneficially active socioeconomic involvement of local populations" (IUCN, 1996). Eco tourists are particularly interested in visiting relatively untouched and pristine areas (Buckley, 2009; Kimengsi, 2014) with the goal to view, admire, enjoy, learn, and leave limited impact, while serving as a livelihood support or diversification strategy. Nonetheless, the meaning of ecotourism may mean different things to different people (Kipper, 2013).

The evolution of the concept of ecotourism could be traced from the 1980s, which coincides with the grounding of the concept of sustainable development (Mowforth, 2003; Fennell, 2008). It evolved from growing concerns about the negative environmental and socioeconomic effects of mass tourism development (EGA, 2008). It has become everything that mass market tourism is not. Rather than isolating tourists from local communities in all-inclusive resorts, it features engagement with local culture, nature, and communities. Rather than despoiling the environment, it seeks to protect and enhance it (Langoya and Long, 2016). See fig.1.

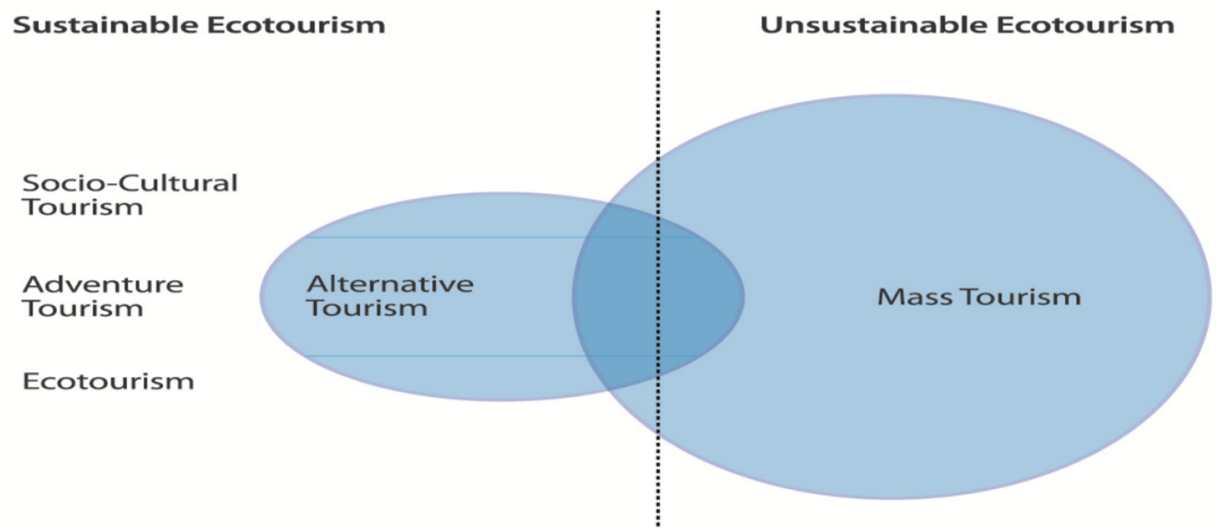

Figure 1: Conceptual model of tourism and ecotourism (Eriksson, 2003) 
Ecotourism is an important and rapidly growing "niche market" within the global tourism industry, which offers an opportunity to develop products that can contribute to environmental conservation, socio-economic and cultural objectives by providing livelihoods for local communities and giving value to the maintenance of local traditions and culture (UNECA, 2011). The sector is increasingly accepted as a suitable alternative for sustaining rural livelihoods and its choice defined as including arts and crafts sales/cultural heritage promotion, wilderness/museum visits, cultural festivals, and conservation education (Jude et al, 2019).

The contribution of ecotourism to rural livelihoods and livelihood diversification has received significant research attention (Bandyopadhyay, 2004; Scheyvens, 2007; Hein, 2011; Truong et al., 2014). Several studies that employed quantitative approaches have emphasized the role of ecotourism activities as determinants of livelihood outcomes (Muchapondwa, 2003; Bandyopadhyay et al., 2004; Turpie at al., 2006; Mitchell, 2012).

Ecotourism could be as a good example of alternative income generation and off-farm activities which benefit local communities while achieve the conservation goals of natural resources (EFCOT, 2003; Turpie at al., 2006; Mitchell, 2012). Furthermore, assessment of ecotourism or simple nature tourism does not need more facilities and it depends on locally obtained facilities or natural capital of the poor that can be managed locally (Scwenk, 2002). Ecotourism could be a link between protected areas and local communities by generating income for local communities while conservation goals of protected areas achieved. It is very important where the ecosystem is fragile and other forms of natural resource management might be impossible (Brodnig, 2006).

Ethiopia is a country which is endowed with the vast array of ecotourism resources including cultural, historical, and archaeological and natural resources which are ideal for the development of sustainable ecotourism ventures (Sewnet, 2017). The county is land of multiple tourist attractions and a visitor friendly people who are conscious of its historical, cultural and natural heritages (Ayalew, 2009). It possesses a plethora of tourist attractions, yet tourism infrastructure is at its infancy; tourist products are poorly maintained; access to tourist products are difficult and can be inappropriately expensive; and there is a lack of marketing to attract tourists to the country, and a lack of marketing of tourist attractions once tourists are in the country (Robinson et al., 2016). By considering the above reality, the aims of this review paper are:

$>$ To understand the contemporary knowledge regarding ecotourism industry in general,

$>$ To clearly identify the role and status of ecotourism industry particularly in Ethiopia

$>$ To identify the impacts of ecotourism industry especially towards local community

$>$ To suggest future scenario for ecotourism industry based on different literatures.

\section{Linkage of Ecotourism and Protected Areas (from out to Ethiopia)}

Ecotourism and protected areas in various forms are two concepts that relate to each other (Aramde et. al., 2012; Lambi et al., 2012). Today protected areas are aimed at conserving biodiversity and large scale of natural ecosystems even though increasingly facing a number of challenges (Wearing and Neil, 1999). Protected areas are important destinations for a growing tourism sector like ecotourism given that it uses diverse nature, landscapes and biodiversity as major attractions (Kimengsi, 2014; Eshun et al., 2016). To ensure that ecotourism can occur, the areas concerned must be preserved and the natural resource base including its flora and fauna must be conserved under the role of protected areas (Kimengsi, 2014; Eshun et al., 2016). Often the location of protected areas is also the location of the homes of entire communities where communities source various resources to sustain themselves, their families and their livelihood (Lambi et al., 2012). If properly planned and managed ecotourism may minimize the environmental impacts while significantly contributes to the protected areas (Strasdas, 2002).

Protected areas are biodiversity conservation centers and major tourism assets for a nation, particularly for developing countries like Ethiopia through providing sustainable benefit to the local community while supporting for the maintenance and rehabilitation of the protected areas themselves (Aramde F. et. al., 2012; Du et al., 2015). Protected areas are essential for biodiversity conservation and they are the cornerstones of virtually all national and international conservation strategies, set aside to maintain functioning natural ecosystems, to act as refuges for species and to maintain ecological processes that cannot survive in most intensely managed landscapes (Dudley, 2008).

Protected areas act as benchmarks against which we understand human interactions with the natural world (Aramde et. al., 2012). Today they are often the only hope we have of stopping many threatened or endemic species from becoming extinct (Dudley, 2008). Protected areas are policy instruments for preservation and sustainable use of natural resources vital tool to achieve conservation and sustainable development with a growing acknowledgement of diversified expectation for protected areas (Du et al., 2015). The need for protected areas to optimize revenue and other finance streams in order to supplement government grant funding is widely recognized from time to time (Kelboro and Stellmacher, 2012).

Ethiopia has variety of protected areas with in different places in the regions that can be managed either government or community based sectors (EWCA, 2013). These are: 22 National parks (NP), 2 Wildlife sanctuaries (WS), 5 Wildlife Reserves (WR), 10 Community Conservation Areas (CCA), 21 Controlled Hunting areas (CHA) 
and 4 Biosphere Reserves (BR). Being known by its oldest record of formalized conservation effort in Africa, protected area management, development and utilization policy in Ethiopia has been subject to a series of paradigm changes since the establishment of Ethiopian Wild Life Organization in 1965 (Derera, 2017).

The country's geology, archeological sites and landscape as well as cultural diversity have been contributed for tourism development and promotion (Robinson et al., 2016). However, the wildlife tourism solely dependent on protected areas, primarily national parks and sanctuaries of the country. Ethiopia's wildlife is one of the richest and most diversified in Africa with several of its protected areas and wetlands (Amare, 2015b). Those are icons for ecotourism sector development. Out of the total wildlife resources, more than 320 mammals (39 endemic), 918 birds (19 endemic), 240 reptiles (16 endemic), 71 amphibians (30 endemic) and 172 fishes (38 endemic) species are recorded in Ethiopia and about 7000 species of plants (12-15\% are endemic (Vreugdenhil et al., 2012; Amare, $2015 \mathrm{~b}$ ). The country also has a wide variety of wildlife habitats ranging from alpine moor lands, to lowland savannahs with extensive wetlands. Having evolved in relative ecological isolation from the rest of the African mainland, Ethiopia contains approximately $40 \%$ of all land above $2,500 \mathrm{~m}$ in altitude (EWCA, 2013).

\section{Concept of Eco Lodges and Community Based Ecotourism (from out to Ethiopia)}

The International Ecotourism Society (TIES, 1990) defines eco-lodges as including three main components: conservation of neighboring lands, benefits to local communities and interpretation to both local populations and guests. Eco lodges are an exciting and potentially extremely viable strategy for achieving all the tenants of ecotourism and more specifically community based eco-tourism (Zerubabel and Tsion, 2019). Ecotourism has the greatest pro-poor impact on rural communities because the customer comes to the facility/product creating room for direct sell thus fostering the creation of the economic multiplier effect (Manu et al., 2012).

Community-based ecotourism helps improve standard of living for example through increased disposable income of individuals (Manu et al., 2012). Besides these, there is an underlying concept of development of community-based ecotourism which is empowerment of local people (Ashley, 2001). In particular, the concept of empowerment of host communities can be divided into four different categories: Economic, psychological, social and political (Manu et al., 2012; Ashley, 2001). In economic terms, ecotourism generates long-term benefits that are distributed equitably within the host communities and can be used for the constant improvement of the community's infrastructure.

Moreover, ecotourism can contribute to the psychological empowerment of the local people by enhancing their sense of self-esteem and by cultivating pride for their cultural and natural heritage (Ashley, 2001; Manu et al., 2012). This happens because ecotourism reveals to the public the value of host community in terms of natural beauty or cultural uniqueness. In addition, ecotourism may strengthen social bonds within the community by promoting cooperation among its members. Finally, ecotourism brings about political empowerment, since it creates a forum for the expression of peoples' voices concerning issues of local development (Scheyvens, 1999; Ashley, 2001; Manu et al., 2012).

Another important benefit of community participation in ecotourism which is somewhat related to the economic benefits is conservation (Dixey, 2005; Li, 2006; West et al, 2006; Epler Wood \& Jones, 2008; Byrd et al., 2009; Sewnet, 2017). Community-based ecotourism (CBE) is seen as a viable model for achieving conservation and improved livelihoods for park-fringe communities (Ishmael, 2017). CBE by its nature ensures the sustainable use of biodiversity and this offers the opportunity for host communities to derive revenue and employment (Mowforth and Munt, 2009). Bhanoo (2015) has also argued that CBE leads to conservation through rural development because villagers and local people are more inclined to support biodiversity conservation and follow park rules if they were involved in it.

It has been further argued that community participation helps to reduce conflicts and misunderstandings among host communities, park authorities and tourists (Ishmael, 2017). Hardy, Beeton, and Pearson (2002) indicated that community participation is believed to reduce opposition to tourism development, minimize negative impacts and revitalize the economies of host communities. Another way by which it helps to reduce conflicts is through improvement in people-park collaborations which contributes to the understanding of local issues and promotes knowledge sharing (West et al, 2006). See fig.2. 


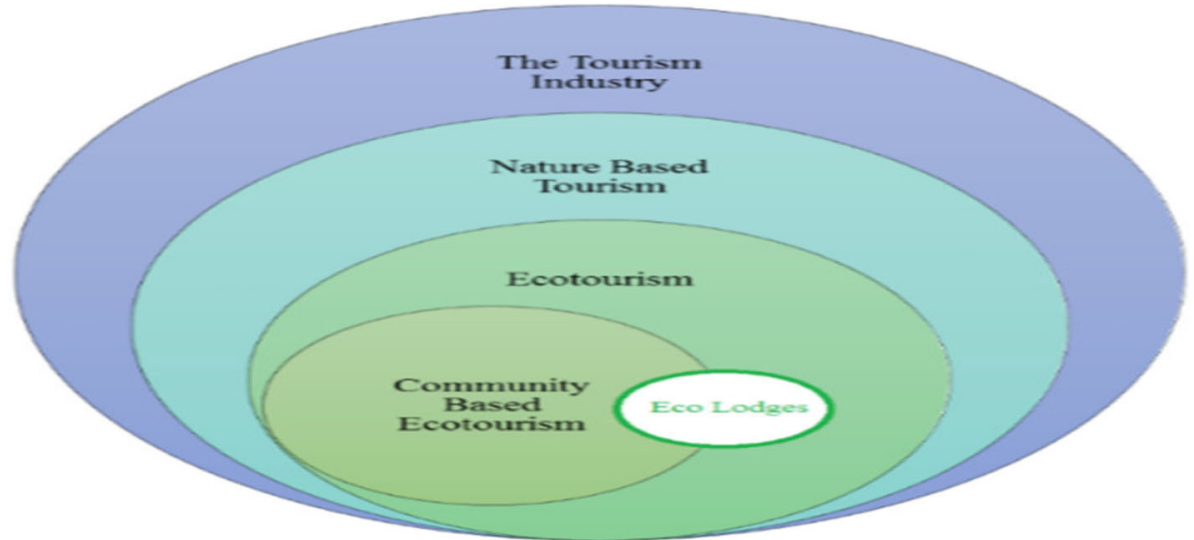

Figure 2: The tourism industry and Eco lodges (Zerubabel and Tsion, 2019)

Numerous community-based ecotourism initiatives and associations have been developed across Ethiopia in the last decade (Sisay, 2004; Carmen, 2017). Regions like Tigray, Amhara, Oromia, and SNNPR are actively promoting these alternative development models and some locations of active community-based ecotourism include the Simien and Bale Mountains national parks, Menze Guassa, Lake Tana, Lalibela Meket, Lake Ziway, Wenchi Crater, Lake Langano, Lake Hawassa, Lake Abaya and Chamo, Abune Yossef, Mekedella, Adawa and Yirgalem also specifically good destination (Carmen, 2017). According to the author in Ethiopia, as in many other destinations worldwide, these projects are seldom based on realistic assessments of the market potential, lack good feasibility studies and links with the commercial channels are not well established from the outset. Additionally, Adaba-Dodola, which is financially and technically supported by the German Agency of Technical Cooperation or GTZ (now GIZ) on the northern slopes of the Bale Mountains in Oromia National Regional State and a pilot ecotourism project on Semen Mountains National Park (Sisay, 2004).

\section{Impacts of Ecotourism industry (from out to Ethiopia)}

Ecotourism first and foremost, has been associated with positive impacts on the destination economies, with the sector being noted as the fastest growing within the tourism industry (Eshun et al., 2016; Hugo and Nyaupane, 2016; Irizarry, 2017). Positive economic impacts are generally linked to the creation of jobs (Andereck et al., 2005; Tyrrell et al., 2013; Venkatesh and Gouda, 2016) which can have knock-on positive social impacts in terms of the employment of those from the destination areas thereby improving the local quality of life. However, the possibility that positive impacts are not the only outcome must also be considered (Wishitemi et al., 2015). Socially, communities and locals from the destination areas can suffer the negative consequences of ecotourism through being denied access to the protected areas that are reserved for ecotourism (Das and Chatterjee, 2015) thus leading to an inability to access their source of livelihoods.

From an environmental perspective, drawing on the aforementioned definition of ecotourism such tourism could positively impact on environmental conservation and preservation efforts thereby contributing to the sustainable use of natural resources (Lu et al., 2016; Boley and Green, 2016; Irizarry, 2017). However, the above too might be linked to the possible negative social impacts, compromising the livelihoods of the locals and the communities that rely on the natural resource base for sustenance (Stronza and Gordillo, 2008; Poudel et al., 2016). Furthermore, community participation, or lack thereof in the conservation efforts stemming from ecotourism can shape the positive or negative attitudes of individuals or groups (Wishitemi et al., 2015).

The Sustainable Livelihood Framework (SLF) is an approach that provides an understanding of the livelihoods of the poor (Allison \& Ellis, 2001; Agarwala et al., 2014). The Department of International Development included the sustainable livelihood approach as an integral aspect of their pro-poor strategies and policies (Solesbury, 2003; Agarwala et al., 2014). As Chambers and Conway (1992) note "a livelihood in its simplest sense is a means of gaining a living. The SLF includes five assets, namely the natural, physical, human, financial and social capital assets. The access to and the interaction with such assets determines the livelihood of those involved (Allison \& Ellis, 2001). Although the ecotourism activities present an opportunity in which the locals can engage, it is necessary to secure alternate forms of generating income due to the seasonality and resultant instability of the industry (Vyasha and Tembi, 2018) some times. See fig.3 


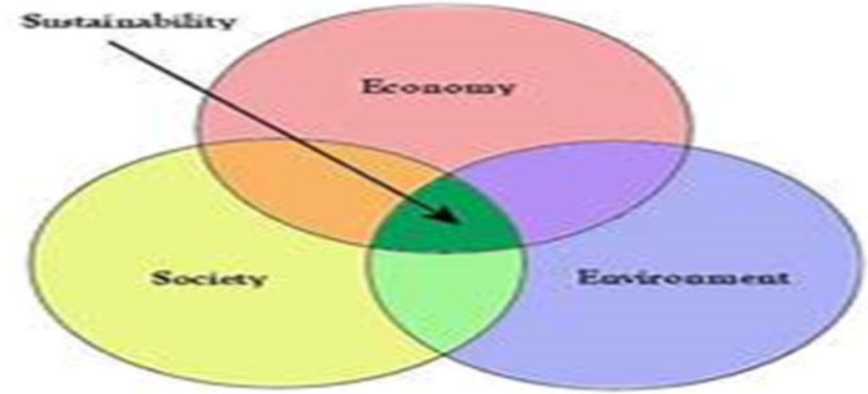

Figure 3: The notion of sustainability under the three pillars (source: Zerubabel and Tsion, 2019)

Although it has been difficult to calculate the size and growth rate of ecotourism, a range of estimates indicate that it has become the fastest growing sub-sector of the tourism industry (Du et al., 2015). During the 1990s, the annual growth in demand for ecotourism was said to range from 10 to 34\%, while in 2004, the UNWTO estimated that ecotourism and nature tourism were growing three times faster than conventional tourism industry as a whole. In 2005, the International Tourism Network also rated ecotourism as one of the fastest growing sub-sectors in the tourism industry with an annual growth rate of 5\% worldwide representing $6 \%$ of the world Gross Domestic Product and $11.4 \%$ of all consumers spending (Honey, 2008). Ecotourism activities have been expanding rapidly over the past decades worldwide and further growth is expected in the future (UNWTO, 2002).

Ethiopia is an Eastern African country with the home of 14 natural, cultural and mixed property heritages registered on UNESCO which spreads all over the whole country and has great potential to develop itself as a tourist destination (MOCT, 2016). Tourism and Travel sector has direct, indirect and induced impact on the Ethiopian economy. In 2014, the direct contribution from tourism and travel to Ethiopian GDP was US\$ 2,057.8 million (4.1\% of total GDP), and this contribution is forecasted to rise by $1.2 \%$ in 2015 to reach US $\$ 3,287.4$ million. Cognizant of the vital role that the sector plays in energizing the national economic growth, the Government of Ethiopia included tourism in the list of priority economy builder sectors (MoFED, 2012).

International Bank for Reconstruction and Development (2006) study on the tourism sector excluding foreign exchange earnings from Ethiopian Airlines shows that this sector generates approximately 132 million USD in direct income from different services such as accommodation, transportation, meals and drinks, traveler fees \& arts and crafts purchases, making it the third highest exchange wage earner (MoCT Report, 2014/2015). The number of foreign tourists those visited the country has increasing significantly from year to year as of 227,398 in 2005 to 427,286 in 2009 and then to 523,438 in 2011 and a lot of significantly raised for the year 2014 to 770,425 foreign traveler arrivals were registered this is because of Ethiopia was highly participate in promoting those heritages found in the country to the whole world (MoCT Report, 2014/2015) as shown in fig. 4.

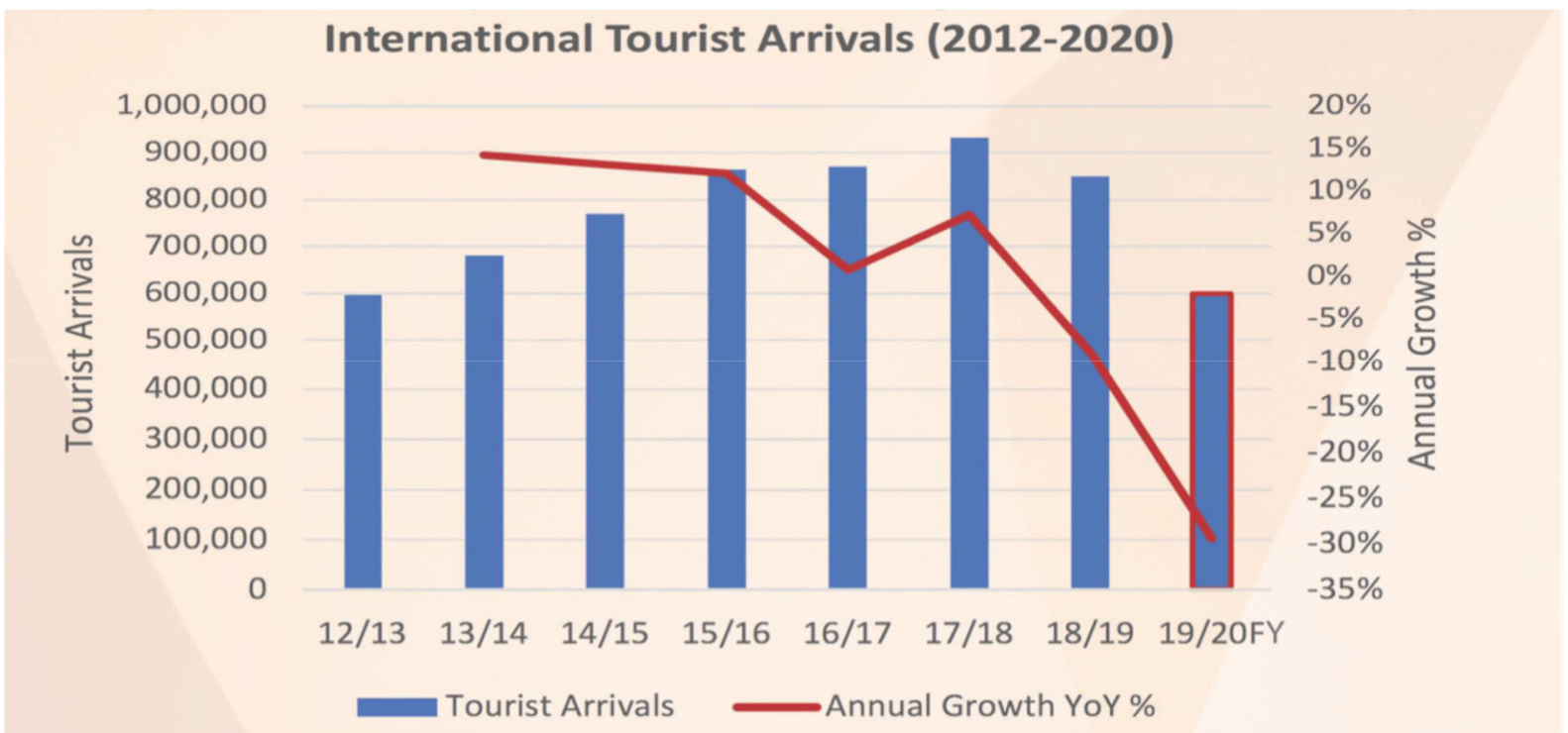

Figure 4: International Tourist Arrivals from 2012- 2020 in Ethiopia (Source: UNWTO, 2020)

Based on the information of international tourist arrivals, even though there was an incremental pattern of tourist arrivals in the late 2017 to early 2019 (reached more than 900,000 arrivals), the arrivals became declined then due to novel coronavirus (COVID-19) happened globally (Mahder et al., 2020).

Latest report of World Travel and Tourism Council's (WTTC, 2019) on Ethiopia's Travel and Tourism with 
reference to financial gain revenue tourists seventy seven were came from international travelers and twenty third from domestic travelers primarily for leisure activities that accounts seventy nine and therefore the remaining twenty first travelers were came for the business activities as a result of this the economy driven from this sector were grew by $48.6 \%$ in 2018 and makes the largest of any country around the globe which creates a revenue of $\$ 7.4$ billion as we compares from 2017 and it shows an increment of $\$ 2.2$ billion. Owing to this tourism and travel contributes $9.4 \%$ of country economy and it creates 2.2 million jobs, or $8.3 \%$ total employment of the country (Mahder et al., 2020).

As of UNWTO (2020) report, the tourist arrivals in African country are making variation from Nov.2018Jan.2019 in some selected countries. In the specified year, there is incremental pattern for Ethiopia as shown in fig. 5 .

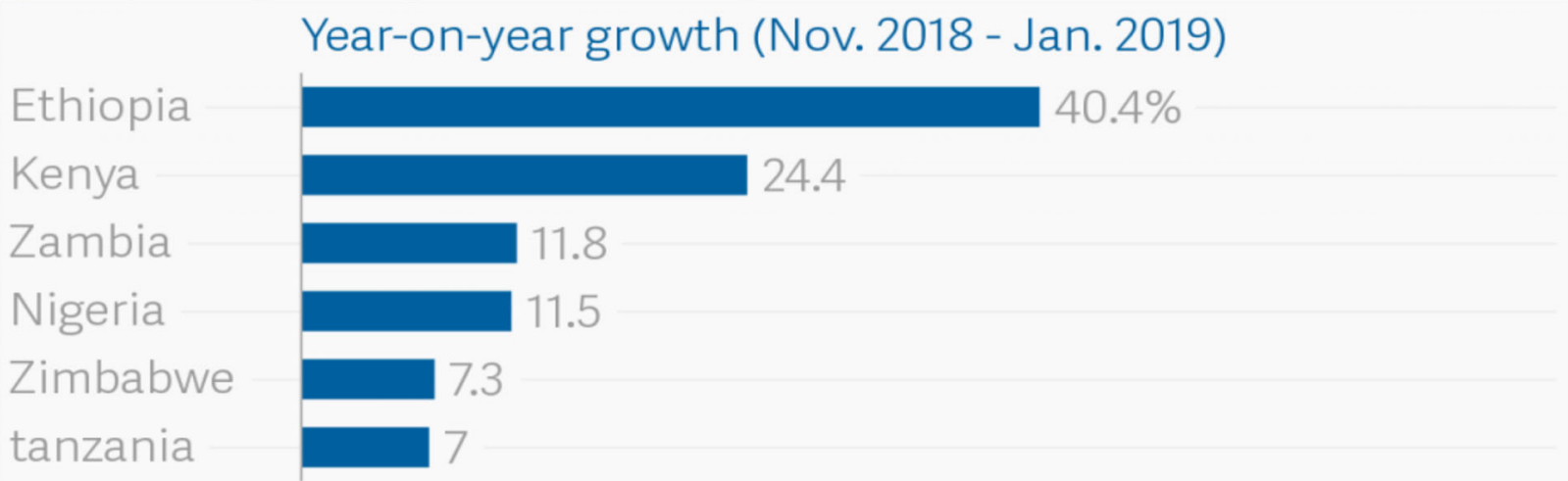

Figure 5: Growth of travel and tourism from Nov.2018- Jan.2019 in Africa (Source: UNWTO, 2020)

The hotel Industry plays a major role in the development of Ethiopian economy, besides from its contribution to GDP; it creates jobs opportunity extends from unskilled persons such as, cooker, receptionists, cleaners, security guards to skilled higher management staffs. Furthermore, now this industry plays a crucial source of employment which accounts $3.8 \%$ of total employment in 2013 representing 985,500 jobs directly and this is forecast to grow by $0.1 \%$ in 2014 to 986,000 (3.6\% of total employment) In the country (Sustainable Tourism master plan of Ethiopia, 2015 -2025).

Table 1: Incoming operators in Ethiopia offering community experiences, Rate from 'least important' (1) to 'most important' (5) (Source: CBI Market Scan, 2017, cited in, Carmen, 2017).

\begin{tabular}{|c|l|c|}
\hline No. & \multicolumn{1}{|c|}{ Assessment of destination } & Ethiopia (1-5) \\
\hline 1 & Visiting local communities & 4 \\
\hline 2 & Walking or cycling through communities & 4 \\
\hline 3 & Lunch break in community & 3 \\
\hline 4 & Home-stays or community lodges & 3 \\
\hline 5 & Bed and breakfast accommodation & 3 \\
\hline 6 & Cooking courses in local home & 3 \\
\hline 7 & Participation in daily (farm) life activities & 2 \\
\hline 8 & Handicraft demonstration & 2 \\
\hline 9 & Other: hair-style/hair pleating & 1 \\
\hline 10 & Other: making local brewery & 1 \\
\hline 11 & Other: village tours including weaving & \\
\hline
\end{tabular}

In general, Tourism is a back bone in Ethiopia significantly it generates foreign currency and it ensure high involvement in creating country GDP. Besides to this it supports 2.2 million jobs of the country (Mahder et al., 2020).

\section{Ecotourism SWOT analysis in Ethiopia}

By definition, ecotourism prefers small number of tourists but in many cases, control and monitoring of the carrying capacities of target areas is often difficult. The impact of tourism on the environment includes depletion of natural resources, pollution, soil erosion, natural habitat loss, increased pressure on endangered species and heightened vulnerability to forest fires (Sri Lanka Tourism Development Authority, 2011). Negative impacts from tourism occur when the level of visitor use is greater than the environment's ability to cope with this use within the acceptable limits of change (Kuuder et al., 2013; Wishitemi et al., 2015). There are arguments about the influx of tourists, economic benefits from tourism and infrastructure development which suggest that if these are not managed properly, they may turn ecotourism into mainstream mass tourism (Kuuder et al., 2013).

The tourism sector is a major contributor to socio-economic development and can be used as a tool to reduce poverty at the national, regional and rural areas (Manu et al., 2012; Ishmael, 2017). Ecotourism generally poses 
both positive and negative effects to participating communities (Kuuder et al., 2013; Wishitemi et al., 2015).

The ecotourism potentials of Ethiopia has been facing a number of threats due to increasing human population and livestock pressures like heavy grazing of under story; the cutting of trees for construction, farm tools and fuel; expansion of cultivated area (Belachew, 2016). Even though natural resources in Ethiopia have great contribution for the development of tourism in general and ecotourism in particular, most of natural resources are highly exposed to degradation which directly affect ecotourism sector (Belachew, 2016). Deforestation is one of the major factors contributing to land degradation by exposing the soil to various agents of erosion which in turn greatly affects agricultural productivity.

Table 2: Ecotourism SWOT analysis in Ethiopia (adopted from UNECA, 2011 \& Adibe, 2017)

\begin{tabular}{|c|c|c|c|}
\hline Strength & Weakness & Opportunities & Threat \\
\hline $\begin{array}{l}\text { Some are gazetted and } \\
\text { well conserved }\end{array}$ & $\begin{array}{l}\text { Most of the protected } \\
\text { areas are on paper only }\end{array}$ & $\begin{array}{l}\text { Existence of protected } \\
\text { areas with its huge } \\
\text { resources }\end{array}$ & $\begin{array}{l}\text { Extinction or near } \\
\text { extinction of the floras and } \\
\text { faunas }\end{array}$ \\
\hline $\begin{array}{l}\text { Community aware about } \\
\text { historical resources }\end{array}$ & $\begin{array}{l}\text { Unstable and } \\
\text { unpredictable politics }\end{array}$ & $\begin{array}{lrr}\text { Ethiopia } & \text { has } & \text { a } \\
\text { remarkable } & & \text { ancient } \\
\text { history } & & \\
\end{array}$ & $\begin{array}{l}\text { Extinction of extinction of } \\
\text { some historic resources }\end{array}$ \\
\hline $\begin{array}{l}\text { Some cultures promoted } \\
\text { and conserved well }\end{array}$ & $\begin{array}{l}\text { Social insecurity and low } \\
\text { benefits }\end{array}$ & $\begin{array}{l}\text { Ethiopia has rich of } \\
\text { culture }\end{array}$ & $\begin{array}{l}\text { Extinction of extinction of } \\
\text { some cultural resources }\end{array}$ \\
\hline $\begin{array}{l}\text { Some infrastructure } \\
\text { development }\end{array}$ & $\begin{array}{l}\text { Economy of the country } \\
\text { depend on donor } \\
\text { countries }\end{array}$ & $\begin{array}{l}\text { Vast agrarian resources } \\
\text { and landscapes }\end{array}$ & $\begin{array}{l}\text { probability to stop due to } \\
\text { financial and corruption }\end{array}$ \\
\hline $\begin{array}{l}\text { Railways and thermal } \\
\text { energy source }\end{array}$ & $\begin{array}{l}\text { Development begins and } \\
\text { pauses in the middle }\end{array}$ & $\begin{array}{l}\text { Educated and capable } \\
\text { resource of employee for } \\
\text { new investors }\end{array}$ & $\begin{array}{l}\text { Low technology to extract } \\
\text { and manage available } \\
\text { resources }\end{array}$ \\
\hline $\begin{array}{l}\text { Success lighted up in } \\
\text { Ethiopian Millennium to } \\
\text { boost the positive images } \\
\text { of Ethiopia partially }\end{array}$ & $\begin{array}{l}\text { Insufficient of amount of } \\
\text { modern tool and high } \\
\text { positive image didn't } \\
\text { reflected for others }\end{array}$ & $\begin{array}{l}\text { International airport } \\
\text { which is comfortable } \\
\text { and preferable and } \\
\text { potential resources }\end{array}$ & $\begin{array}{l}\text { Sometime negative images } \\
\text { over through positive one, } \\
\text { make country under } \\
\text { blacklist }\end{array}$ \\
\hline $\begin{array}{l}\text { Positive culture of } \\
\text { religious living together } \\
\text { peacefully }\end{array}$ & $\begin{array}{l}\text { Enhancement of } \\
\text { religious collaboration } \\
\text { not done }\end{array}$ & $\begin{array}{l}\text { Availability of varies } \\
\text { religious in the country }\end{array}$ & $\begin{array}{l}\text { Conflict happened among } \\
\text { religious groups seldom }\end{array}$ \\
\hline $\begin{array}{l}\text { Some of resources } \\
\text { promoted and recognized } \\
\text { like by UNESCO }\end{array}$ & $\begin{array}{lr}\text { Low conservation, } \\
\text { preservation and low } \\
\text { attention } \\
\text { government }\end{array}$ & $\begin{array}{l}\begin{array}{l}\text { Many cultural and } \\
\text { religion }\end{array} \\
\text { monuments and castles }\end{array}$ & $\begin{array}{l}\text { Probability of extinction } \\
\text { or near to extinction in the } \\
\text { long run if preserved }\end{array}$ \\
\hline $\begin{array}{l}\text { Well-developed culture of } \\
\text { tourist management in } \\
\text { some places by all }\end{array}$ & $\begin{array}{l}\text { Low follow up and low } \\
\text { expansion of those } \\
\text { culture to all areas }\end{array}$ & $\begin{array}{l}\text { Deep-rooted } \\
\text { Community's culture of } \\
\text { guest respect ion }\end{array}$ & $\begin{array}{l}\text { Expansion of bad cultures } \\
\text { from tourist to local areas } \\
\text { like children begging }\end{array}$ \\
\hline $\begin{array}{l}\text { Private companies } \\
\text { venturing into offering } \\
\text { Eco products: different } \\
\text { tour companies }\end{array}$ & $\begin{array}{l}\text { Poor quality service } \\
\text { provision-untrained and } \\
\text { poorly skilled tour guides }\end{array}$ & $\begin{array}{lr}\text { Comfortably } & \text { of } \\
\text { resources } & \text { and } \\
\text { landscapes } & \text { existences } \\
\text { for the interested people }\end{array}$ & $\begin{array}{l}\text { Low ownership and } \\
\text { conflict existence through } \\
\text { time }\end{array}$ \\
\hline $\begin{array}{l}\text { Existence of Ecotourism } \\
\text { Association of Ethiopia } \\
(\text { EAE) }\end{array}$ & $\begin{array}{l}\text { Existing policies and } \\
\text { regulatory frameworks } \\
\text { not explicit on } \\
\text { ecotourism }\end{array}$ & $\begin{array}{l}\text { Varity of place or } \\
\text { resources suitable to } \\
\text { establish associations }\end{array}$ & $\begin{array}{l}\text { Seasonality and } \\
\text { dependence of the market } \\
\text { on feigners mainly }\end{array}$ \\
\hline
\end{tabular}

\section{Global Competitiveness of Ecotourism in Ethiopia}

Although Ethiopia is well known for its historical tourism attractions and resources and has been visited by millions of foreigners, the industry of the country is still not at the level where it deserves to be (Feseha, 2011). The World Bank (2008) reported that Ethiopia's competitiveness in terms of tourism resources especially cultural tourism is better when compared to our neighbors'. But when the comparison is made in terms of tourism product development (accessibility), the World Economic Forum (2015) report suggested that the country needs to improve a lot. The World Economic Forum (2017) ranked Ethiopia $116^{\text {th }}$ (out of 136 countries) in its Travel and Tourism Competitiveness Index (TTCI). This rank follows the gradual improvement achieved in the last years but Ethiopia still lags behind other African countries, well established tourism destinations such as Kenya, Tanzania, Rwanda and Uganda (EU Market Scan. CBI, 2017). Ethiopia's relative lack of competitiveness is echoed in a number of studies. 
Table 3: Travel and Tourism Competitiveness Index (TTCI) based on 14 pillars (source: EU Market Scan CBI, 2017-cited in, Carmen, 2017).

\begin{tabular}{|c|c|c|c|}
\hline \multirow[b]{2}{*}{ Indicator } & \multicolumn{2}{|c|}{ Ranking - ETHIOPIA } & \multirow[b]{2}{*}{$\begin{array}{c}\text { Direction of } \\
\text { change }\end{array}$} \\
\hline & $\begin{array}{c}2015 \\
\text { (141 countries) }\end{array}$ & $\begin{array}{c}2017 \\
\text { (136 countries) }\end{array}$ & \\
\hline Natural Resources & 63 & 69 & 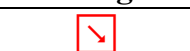 \\
\hline Price in Travel and Tourism & 69 & 64 & 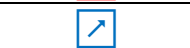 \\
\hline Environmental Sustainability & 76 & 56 & 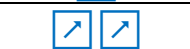 \\
\hline Cultural Resources & 79 & 70 & \begin{tabular}{|l|}
$\nearrow$ \\
\end{tabular} \\
\hline Safety and Security & 80 & 99 & $\searrow \searrow$ \\
\hline Air Transport Infrastructure & 90 & 111 & $\searrow \backslash$ \\
\hline Affinity /International Openness & 93 & 97 & $\searrow$ \\
\hline Health and Hygiene & 104 & 102 & T \\
\hline Policy Regulations /Business Environment & 116 & 118 & $\searrow$ \\
\hline Prioritization of Travel and Tourism & 118 & 115 & 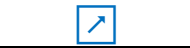 \\
\hline Ground Transport Infrastructure & 123 & 90 & 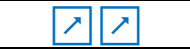 \\
\hline Human Resources & 126 & 125 & $\nearrow$ \\
\hline Tourism Infrastructure & 134 & 129 & 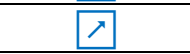 \\
\hline ICT Infrastructure & 137 & 125 & 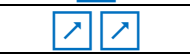 \\
\hline Overall ranking & 118 & 116 & $\nearrow$ \\
\hline Overall ranking among sub-Saharan countries & 17 (out of 31) & 15 (out of 30) & 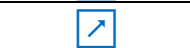 \\
\hline
\end{tabular}

Quite surprisingly, Ethiopia received its best score in environmental sustainability (based on environmental regulations, sustainability of travel, threatened species, and waste water treatment), ranked $56^{\text {th }}$ in 2017 compared to $\mathrm{a} 76^{\text {th }}$ position in 2015 . Other areas with best score were price competitiveness (based on factors like price parity, airport charges, hotel prices) -ranked $64^{\text {th }}$ - and natural resources (based on number of World Heritage natural sites, quality of the natural environment, total known species) - ranked $69^{\text {th }}$. It also scored favorably on cultural resources (from $79^{\text {th }}$ in 2015 to $70^{\text {th }}$ in 2017) and ground transport infrastructure (from $123^{\text {rd }}$ in 2015 to $90^{\text {th }}$ in 2017). All pillars can be understandable from the above table accordingly.

\section{Conclusion}

The ecotourism industry is a major contributor to socio-economic development and can be used as a tool to reduce poverty at the national, regional and rural areas. Although Ethiopia is well known for its historical tourism attractions and resources and has been visited by millions of foreigners, the industry is still not at the level where it deserves to be, which may fever attention to assure positive benefits in all dimension. Exploring untouched attraction areas and preserving/conserving those icons for the future may perpetuate sustainability of the industry. Promoting the positive image of the country towards main international and domestic tourist arrivals may enhance tourist flow and side by side infrastructure development is crucial. Based on this conclusion, the following recommendations are forwarded.

$>$ Detail structured information from scholars needed to explore new innovation which may possible and effective to understand/ manage impacts of tourism or ecotourism industry.

$>$ An awareness campaign should be intensified to target on increasing both domestic and international tourist arrivals at the destination leading to increase in revenue in the community well.

$>$ The driving factor of Ecotourism (pull and push) factors should be considerable issues for further impact management by stakeholders.

$>$ Enhancing local investors in the industry may reduce conflict of ownership for the sector.

\section{Acknowledgement}

I'm very much grateful to the inhabitants of all staff members of Bule Hora University, Department of Natural Resources Management for their valuable advice, provision of materials and necessary supports during my work.

Competing Interests: Author declared no competing interests exist.

Author's Contribution: The author read and approved the final manuscript.

Author Profile: Mr. Bayisa Bussa Gonfa was graduated by Master of Sciences in Environmental Sciences from Arba Minch University, Bachelor degree in Wildlife and Ecotourism Management from Hawasa University. Worked for more than four years as ecologist at Nechsar National park and now serving Bule Hora University as a Lecturer from the last four years. 


\section{References}

Adibe A. (2017). Tourism SWOT analysis in Ethiopia.

Agarwala, M.; Atkinson, G.; Fry, B.P.; Homewood, K.; Mourato, S.; Rowcliffe, J.M.; Wallace, G. \& Milner Gulland, E.J. (2014). Assessing the relationship between human well-being and ecosystem services: A review of frameworks. Conservation and Society, Vol. 12, No. 4, 437-449.

Amare, A. (2015). Wildlife Resources of Ethiopia: Opportunities, Challenges and Future Directions: From Ecotourism Perspective: A Review Paper. Natural Resources, 6, 405-422.

Allison, E.H. \& Ellis, F. (2001). The livelihoods approach and management of small-scale fisheries. Marine Policy, Vol. 25, No. 5, 377-388.

Andereck, K.L.; Valentine, K.M.; Knopf, R.C. \& Vogt, C.A. (2005). Residents' perceptions of community tourism impacts. Annals of Tourism Research, Vol. 32, No. 4, pp. 1056-1076.

Aramde F., Tsegaye B. and Pananjay GBG., Tiwari K. (2012). The Contribution of Ecotourism for Sustainable Livelihood Development in the Nech Sar National Park, Ethiopia. International Journal of Environmental Sciences 1 (1), 19-25.

Ashley C. (2001). Pro-poor tourism strategies, expanding opportunities for the poor, London: Overseas Development Institute.

Ayalew Sisay (2009). Historical Development of Travel and Tourism in Ethiopia, Addis Ababa, Ethiopia.

Belachew B. (2016). Review on Ecotourism Opportunities and the Challenges for Natural Resource Management in Ethiopia. Journal of Tourism, Hospitality and Sports. 21, 2312-5179.

Bandyopadhyay, S., Shysamsundar, P., Wang, L., Humavindu, M.N. (2004). Do Households Gain from Community-Based Natural Resource Management? An Evaluation of Community Conservancies in Namibia; DEA Research Discussion Paper, No. 68; The World Bank: Washington, DC, USA.

Bhanoo S. (2015). Community participation in conservation of Great Himalayan National Park. Chennai, India: Notion Press.

Buckley R. (2009). Ecotourism: Principles and Practices; CAB International: London, UK.

Byrd, E. T., Bosley, H. E., \& Dronberger, M. (2009). Stakeholder perceptions of tourism impact in eastern North Carolina. Tourism Management, 30, 693-703.

Carmen A. (2017). Analysis of tourism value chain in Ethiopia. Tourism VCA Ethiopia - Final Report.

Chambers, R. \& Conway, G. (1992). Sustainable rural livelihoods: Practical concepts for the 21 st century. Brighton: Institute of Development Studies (UK).

Das, M. \& Chatterjee, B. (2015). Ecotourism: A panacea or a predicament? Tourism Management Perspectives, Vol. 14, pp. 3-16.

Derera Ketema (2017). Ethiopia: Changes from "People out Approach" Protected Area Management to Participatory Protected Area Management? Insight from Ethiopian Protected Areas. IOSR Journal of Environmental Science, Toxicology and Food Technology (IOSR-JESTFT), Volume 11( 2). PP 49-55.

Dixey L. (2005). Inventory analysis of community based tourism in Zambia. USAID Production, Finance and Technology (PROFIT) Program, Lusaka, Zambia.

Dr Hugo van Zyl (2015). The Economic Value and Potential of Protected Areas in Ethiopia. The Sustainable Development of the Protected Areas System of Ethiopia (SDPASE) project and the Ethiopian Wildlife Conservation Authority (EWCA). Independent Economic Researchers.

Dr. B. M. K. Robinsonand Professor J. A. Jonker (2019). Tourism in Ethiopia: An urgent opportunity for economic diversification. African Journal of Hospitality, Tourism and Leisure. 5(3).

Dudley, N. (2008). Guidelines for Applying Protected Area Management Categories, International Union for Conservation of Nature and Natural Resources, 86 pp., ISBN 978-2-8317-1086-0, Gland, Switzerland.

Du,W., Penabaz-Wiley, S.M , Murithi Njeru, A. and Kinoshita, I. (2015). Models and Approaches for Integrating Protected Areas with Their Surroundings: A Review of the Literature; Sustainability, 7, 8151-8177.

Environmental Grant makers Association (2008). Ecotourism as a Conservation Strategy for Funders: a background briefing, New York, USA.

Epler Wood, M., and Jones, H. (2008). Community-based tourism enterprise in Latin America. Burlington, VT: EplerWood International.

Eshun, G.; Adjei, P.O.W.; Knust, K. \& Segbefia, A.Y. (2016). Beyond business as usual: Implications of tourist experiences for ecotourism development. African Journal of Hospitality, Tourism and Leisure, Vol. 5, No. 2, $1-26$.

Eriksson, H. 2003. "Rhetoric and Marketing Device or Potential and Perfect Partnership? - A Case Study of Kenyan Ecotourism, Umea University, pp 1-8.

Ethiopia Forum for Community Based Tourism (2003). A study into recommendations on establishment of Community Based Tourism Organization to promote, support the growth of Community Based Tourism in Ethiopia and to represent those involved in it. Report paper by consultancy team, November/December p.4.

EU Market Scan. CBI. (2017). Tourism top Ethiopia, Senegal and Zambia. EU Market Scan. CBI. 
Ethiopian Wildlife Conservation Authority (2013). A Traveler's Guide to Bale Mountains National Park. Frankfurt Zoological Society and the Bale Mountains National Park, Ethiopian Wildlife Conservation Authority (EWCA), Addis Ababa.

Feseha, M. (2011). Participatory Tourism: the future of Ethiopian Tourism. Addis Ababa: Addis Ababa University press.

Fennell, D. (2008). Ecotourism: An Introduction, 3rd ed.; Routledge: New York, NY, USA.

Fesika Temesgen (2017). Opportunities and challenges for the development of community based ecotourism in southern Ethiopia: the case of loka abaya national park.

Hardy, A., Beeton, R., \& Pearson, L. (2002). Sustainable tourism: An overview of the concept and its position in relation to conceptualizations of tourism. Journal of Sustainable Tourism, 10(6), 475-496.

Hein, L. (2011). Economic benefits generated by protected areas: The case of the Hoge Veluwe forest, the Netherlands. Ecol. Soc. 16, 13.

Honey M. (2008). Ecotourism and Sustainable development: Who owns Paradise? Island Press Washington DC 2nd edition.

Hugo, N.C. \& Nyaupane, G.P. (2016). Poverty alleviation in Third World countries through tourism development: A comparison study of Costa Rica and Nicaragua. University of Massachusetts, Amherst. Tourism Travel and Research Association: Advancing Tourism Research Globally.

IBRD. (2006). International Bank for Reconstruction and Development/The World Bank 1818 H Street NW.

Irizarry, A. (2017). Exploring the certification of ecotourism ventures as a tool for sustainable development. Unpublished doctoral thesis. Waltham, Mass.: Brandeis University.

Ishmael M. (2017). Benefits and challenges of community-based ecotourism in park-fringe communities: the case of mesomagor of kakum national park, Ghana. Tourism Review International, Vol. 21, pp. 81-98.

TIES (1990). International Ecotourism Society. A Global Membership Organization. A non-prot industry association

IUCN. (1996). Tourism, Ecotourism and Protected Areas. Ceballos-Lascuráin, H., International Union for Conservation of Nature, Gland, Switzerland and Cambridge, UK.

Jude, N. K., Mukong A. K., Balgah R. A., Jürgen P. and Jude K. (2019). Households' Assets Dynamics and Ecotourism Choices in the Western Highlands of Cameroon.

Kassean, H. \& Gassita, R. (2013). Exploring tourists push and pull motivations to visit Mauritius as a tourist destination. African Journal of Hospitality, Tourism and Leisure, 2 (3), 1-13.

Kelboro, G., \& Stellmacher,T. (2012). Contesting the National Park theorem? Governance and land use in Nech Sar National Park, Ethiopia. ZEF Working Paper 104.

Kimengsi, J.N. (2014). Threats to ecotourism development and forest conservation in the Lake Barombi Mbo Area (LBMA) of Cameroon. Journal of International Wildlife Law \& Policy, Vol. 17, No. 4, pp. 213-230.

Kiper, T. (2013). Role of ecotourism in sustainable development, license inTech.

Kuuder, C., Wuleka J., Aalangdong, I. O. (2013). Livelihood Enhancement through Ecotourism; A case of Mognori Ecovillage near Mole National Park, Damongo, Ghana.

Lambi, C.M.; Kimengsi, J.N.; Kometa, C.G. \& Tata, E.S. (2012). The management and challenges of protected areas and the sustenance of local livelihoods in Cameroon. Environment and Natural Resources Research, Vol. 2, No. 3, p. 10.

Langoya, C. \& Long, C. (2016). Local communities and ecotourism development in Budongo Forest Reserve, Uganda. Rural Development Forestry Network. Network Paper, 22e:1-14.

Li, W. (2006). Community decision-making participation in development. Tourism Management, 33(1), $132-143$.

Lu, A.C.C.; Gursoy, D. \& Del Chiappa, G. (2016). The influence of materialism on ecotourism attitudes and behaviors. Journal of Travel Research, Vol. 55, No. 2, pp. 176-189.

Mahder K., Genemo F., Melese Ch. (2020). Impact of Covid-19 on Tourism and Hotels of Ethiopia. Journal of Tourism, Hospitality and Sports, Vol-49. 2312-5179.

Manu, I., Kuuder, C., Wuleka J. (2012). Community-Based Ecotourism and Livelihood Enhancement in Sirigu, Ghana. International Journal of Humanities and Social Science, 2(18).

Ministry of Culture and Tourism (MOCT, 2015). Tourism Statistics Bulletin of 2016.

Mitchell, J. (2012). Value chain approaches to assessing the impact of tourism on low-income households in developing countries. J. Sustain. Tour. 20, 457-475.

MOUDC, 2011 MoFED. 2012. Growth and Transformation Plan 2010/11-2014/15, Ministry of Finance and Economic Development, Addis Ababa. Report pdf.

Mowforth, M., \& Munt, I. (2009). Tourism and sustainability: Development and new tourism in third world (3 ed.). Abingdon, UK: Routledge.

Muchapondwa, E. 2(003) .The Economics of Community-Based Wildlife Conservation in Zimbabwe. Ph.D. Thesis, Goteborg University, Goteborg, Sweden.

Ndlovu, J. (2015). Authenticity, emotion and experience: tourists' motivation for visiting re-enactment sites in 
KwaZulu-Natal. African Journal of Hospitality, Tourism and Leisure, 1-12.

Poudel, S.; Nyaupane, G.P. \& Budruk, M. (2016). Stakeholders' perspectives of sustainable tourism development: A new approach to measuring outcomes. Journal of Travel Research, Vol. 55, No. 4, pp. 465-480.

Scwenk, T. (2002). Potentials for Community Based Eco-Tourism Project in the Area of the Wenchi and Dendi Crater Lakes. Unpublished Paper, for community based eco-tourism studies, West Shewa, Oromia Region, Ethiopia.

Scheyvens, R. (1999). Ecotourism and the empowerment of local communities, Tourism Management, 20(2):245249.

Scheyvens, R. (2007). Exploring the Tourism-Poverty Nexus. Curr. Issues Tour. 10, 231-254.

Sewnet Tesfaye (2017). Challenges and Opportunities for Community Based Ecotourism Development in Ethiopia. African Journal of Hospitality, Tourism and Leisure, Volume 6(3).

Sisay, A. (2004). Adaba-Dodola community- based ecotourism development.

Vreugdenhil, D., Vreugdenhil, A.M., Tilahun, T., Shimelis, A. \& Tefera, Z. (2012).Gap Analysis of the Protected Areas System of Ethiopia, World Institute for Conservation and Environment, USA.

Solesbury, W. (2003). Sustainable livelihoods: A case study of the evolution of DFID policy. London: Overseas Development Institute.

Strasdas, W. (2002). Ecotourism Training Manual for Protected Area Managers. German Foundation for International Development (DSE) Center For Food, Rural Development and The Environment (ZEL) Feldafing and Zschortatu, Germany.

Stronza, A. \& Gordillo, J. (2008). Community views of ecotourism. Annals of Tourism Research, Vol. 35, No. 2, pp. $448-468$.

Truong, V.D.; Hall, M.C.; Garry, T. (2014). Tourism and poverty alleviation: Perceptions and experiences of poor people in Sapa, Vietnam. J. Sustain. Tour. 22, 1071-1089.

Turpie, J.; Barnes, J.; Arntzen, J.; Nherera, B.; Lange, G.-M.; Buzwani, B. Economic value of the Okavango Delta, Botswana, and implications for management. Okavango Development Management Plan. 2006.

Tyrrell, T.; Paris, C.M. \& Biaett, V. (2013). A quantified triple bottom line for tourism: Experimental results. Journal of Travel Research, Vol. 52, No. 3, pp. 279-293.

Venkatesh, R. \& Gouda, H. (2016). Eco-tourism - planning and developmental strategies. Global Journal for Research Analysis, Vol. 5, No. 12, pp. 420-422.

Vyasha Harilal and Tembi M Tichaawa, (2018). Ecotourism and Alternative Livelihood Strategies in Cameroon's Protected Areas. E u r o E c o n o m i c a. issue 1(37).

UNWTO Tourism highlights for (2010). (http://www.unwto.org/facts/eng/pdf/highlights/

UNWTO. (2020b). International tourist arrivals could fall by $20-30 \%$ in 2020 . Retrieved April 5, 2020, from https://www.unwto.org/news/

United Nations Economic Commission for Africa (2011). Ecotourism in the Intergovernmental Authority on Development (IGAD) Region An untapped potential with considerable Socio-economic opportunities, SubRegional Office for Eastern Africa.

Wearing, S. and Neil, J. (1999).Ecotourism: Impacts, Potentials, and Possibilities. 1sted. Reed Educational and Professional Publishing Ltd 1999, Great Britain.

West, P., Igoe, J., \& Brockington, D. (2006). Parks and peoples: The social impact of protected areas. Annual Review of Anthropology, 35, 251-277.

Wishitemi, B.E.; Momanyi, S.O.; Ombati, B.G. \& Okello, M.M. (2015). The link between poverty, environment and ecotourism development in areas adjacent to Maasai Mara and Amboseli protected areas, Kenya. Tourism Management Perspectives, Vol. 16, pp. 306-317.

World Bank (2009). Tourism in Africa: Harnessing Tourism for Growth and Improved Livelihoods. Washington DC: The World Bank.

World Economic Forum (2015). The Travel and Tourism Competitiveness Index 2015: Growth through Shocks, Geneva: World Economic Forum.

World Economic Forum (2017). The Travel and Tourism Competitiveness Index 2017: Growth through Shocks, Geneva: World Economic Forum.

World Travel and Tourism Council, (2019). Global economic impact \& trends.

Yilma ZA, Reta MM, Tefera BT (2016). The Current Status of Ecotourism Potentials and Challenges in Sheko District, South-Western Ethiopia. J Hotel Bus Manage 5: 143. doi: 10.4172/2169-0286.1000143.

Zerubabel W. and Tsion M. (2019). Eco-Lodges and Tourist Infrastructure Development in and Around Abijata Shalla Lakes National Park; From the Perspective of Evaluating their Sustainability. 